\title{
Efisiensi Protein Ayam Broiler yang Diberi Ampas Tahu Fermentasi dengan Saccharomyces cerevisiae (Protein Efficiency of Broiler Chicken Fed fermented Waste Tofu with Saccharomyces cerevisiae)
}

\author{
Nurhayati Nurhayati*, Berliana Berliana dan Nelwida Nelwida \\ Fakultas Peternakan Universitas Jambi Jl. Raya Jambi - Ma. Bulian KM 15 \\ Kampus Pinang Masak, Mendalo Darat, 36361 \\ *e-mail koresponden : nurhayati_agus@unja.ac.id
}

\begin{abstract}
Intisari
Tujuan dari penelitian ini adalah untuk mengevaluasi pertambahan bobot badan dan efisiensi penggunaan protein pada ayam broiler yang diberi pakan mengandung ampas tahu hasil fermentasi menggunakan Saccaromyces cerevisae. Ampas tahu difermentasi menggunakan Saccharomyces cerevisiae sebanyak 2 \% dengan lama waktu fermentasi 72 jam. Setelah dipanen dianalisa kandungan nutrisinya dan diberikan pada ayam broiler sebanyak 200 ekor selama 5 minggu pemeliharaan. Rancangan yang digunakan adalah Rancangan Acak Lengkap (RAL) dengan 5 perlakuan dengan 4 ulangan. Perlakuannya yaitu $\mathrm{P} 0=\mathrm{Pakan}$ komersil (kontrol), P1 = Pakan komersil $+10 \%$ ampas tahu fermentasi, P2 = Pakan komersil $+20 \%$ ampas tahu fermentasi, P3 = Pakan komersil $+30 \%$ ampas tahu dan P4 = Pakan komersil $+40 \%$ ampas tahu fermentasi. Peubah yang diamati adalah konsumsi ransum, konsumsi protein, dan efisiensi penggunaan protein. Data yang diperoleh di analisis ragam dan pengaruh perlakuan terhadap peubah yang diamati diuji dengan uji Jarak Berganda Duncan. Hasil analisis ragam menunjukkan bahwa penggunaan ampas tahu hasil fermentasi dengan Saccharomyces cerevisiae sampai level 20\% tidak berbeda nyata $(\mathrm{P}>0.05)$ dengan kontrol, tetapi semakin tinggi penggunaannya $(>20 \%)$ dalam pakan nyata $(\mathrm{P}<0.05)$ menurunkan konsumsi pakan, konsumsi proein. Dari hasil tersebut dapat disimpulkan bahwa penggunaan ampas tahu fermentasi dalam pakan broiler dapat digunakan sampai $20 \%$ untuk memperbaiki efisiensi penggunaan protein.
\end{abstract}

Kata kunci; Ampas tahu, Broiler, Efisiensi Protein, Saccharomyces cereviseae

\begin{abstract}
This study aimed to evaluate the body weight gain and protein utilization of broiler chicken fed ration contained different levels of fermented waste tofu with Saccharomyces cerevisiae. Waste tofu was fermented by $2 \%$ of Saccharomyces cerevisiae for 72 hours. Fermented waste tofu was analysed the nutrient content and offered to the 200 chickens for 5 weeks. The study was designed by Completely Randomized Design with five treatments and four replications. The treatments were $\mathrm{P} 0=$ control without waste tofu fermentation, $\mathrm{P} 1=$ commercial feed $+10 \%$ of fermented waste tofu, $\mathrm{P} 2=$ commercial feed $+20 \%$ of fermented waste tofu, $\mathrm{P} 3=$ commercial feed $+30 \%$ of fermented waste tofu, and P4 $=$ commercial feed + $40 \%$ of fermented waste tofu. The measured parameters were feed consumption, protein consumption, and protein utilization efficiency. Data were analysed by analysis of variance and the significant effect were tested by Duncan's Multiple Range Test. Analysis of variance showed that utilisation of fermented waste tofu until $20 \%$ in the ration was not significantly $(\mathrm{P}>0.05)$ different among treatment groups. However, increasing level of fermented waste tofu significantly $(\mathrm{P}<0.05)$ decreased feed consumption, protein consumption. It is
\end{abstract}


concluded that fermented waste tofu might be utilised up to $20 \%$ in the broiler chicken to increase protein utilization efficiency.

Keywords: broiler chicken, protein efficiency, Saccharomyces cereviseae, waste tofu

\section{Pendahuluan}

Pakan merupakan kebutuhan primer dari suatu usaha peternakan dimana dalam budidaya ternak secara intensif biaya pakan mencapai sekitar $70 \%$ dari total biaya produksi (Supriyati, 2003), sehingga harga bahan pakan sangat menentukan biaya produksi. Disamping harga pakan, nilai gizi pakan juga menentukan produksi ternak, dengan nilai gizi yang baik maka produksi ternak semakin baik. Sementara itu, beberapa bahan baku masih diimpor dengan harga mahal. Untuk menekan biaya produksi, dibutuhkan bahan baku yang cukup murah dan mudah didapat dengan gizi yang cukup. Salah satu cara memecahkan kendala tersebut adalah dengan memanfaatkan limbah industri seperti ampas tahu. Ampas tahu bisa dimanfaatkan sebagai pakan ternak (Kaswinarni, 2007)

Di Indonesia Industri tahu merupakan salah satu industri yang memiliki perkembangan pesat. Terdapat 84 ribu unit industri tahu di Indonesia dengan kapasitas produksi mencapai 2,56 juta ton per tahun (Sadzali, 2010). Ampas tahu yang terbentuk besarannya berkisar antara 25-35\% dari produk tahu yang dihasilkan (Kaswinarni, 2007). Menurut
Badan Pusat Statistik (2019), produksi kedelai tahun 2018 sebanyak 982.598 ton atau terjadi peningkatan $82,39 \%$ dari tahun 2017. Jika 25\% dari produksi tersebut digunakan untuk tahu, maka diperkirakan produksi ampas tahu sebanyak 245.649,5 ton, suatu jumlah yang sangat potensial untuk pakan ternak. Ampas tahu dapat dijadikan sebagai bahan pakan sumber protein karena mengandung protein kasar cukup tinggi berkisar antara 23-29\% (Mathius dan Sinurat, 2001) dan menurut Kompiang et al., (1997), kandungan nutrisi ampas tahu adalah 21,3 - 27\%, serat kasar 16 $23 \%$ dan lemak 4,5-17\%.

Pada umumnya limbah yang melimpah ini dapat dimanfaatkan langsung sebagai pakan ternak, tetapi asam amino yang rendah biasanya menjadi faktor pembatas dalam penggunaannya sebagai pakan unggas, selain itu pakan unggas yang berasal dari produk nabati mempunyai kekurangan asam amino lisin dan metionin, sehingga perlu dilakukan upaya agar dapat mencukupi kebutuhan tersebut. Ampas tahu berasal dari kedele dan oleh karena itu anti nutrisi yang terdapat pada ampas tahu adalah sama dengan kedele hanya 
konsentrasinya lebih sedikit karena telah mengalami pengolahan. Di samping itu ampas tahu juga mengandung arabinoxylan yang tinggi yang menyebabkan penggunaannya dalam penyusunan pakan unggas menjadi terbatas. Unggas tidak mampu mencerna arabinoxylan dan bahan tersebut dapat menyebabkan terbentuknya gel kental dalam usus halus yang menyebabkan penyerapan lemak dan energi terhambat. Oleh karena itu perlu dilakukan upaya agar ampas tahu dapat dimanfaatkan secara maksimal oleh unggas, yaitu dengan bioteknologi fermentasi. Bidura et al., (2008), menyatakan bahwa teknologi fermentasi dapat meningkatkan kualitas dari bahan pakan khususnya yang memiliki serat kasar dan antinutrisi yang tinggi. Fermentasi dapat meningkatkan kecernaan bahan pakan melalui penyederhanaan zat yang terkandung dalam bahan pakan oleh enzim-enzim yang diproduksi oleh mikroba. Selanjutnya dijelaskan oleh Oboh dan Elusiyan (2007), bahwa fermentasi dapat meningkatkan kandungan nutrisi bahan karena terjadinya biosintesis vitamin, asam amino esensial dan protein, serta meningkatkan kualitas dan daya cerna protein.

Menurut Suwarni (2000), bahan yang telah mengalami fermentasi akan mudah dicerna dan asam amino serta vitaminnya meningkat. Upaya untuk meningkatkan protein (asam amino) dapat dilakukan dengan fermentasi memanfaatkan jasa mikroba yang mampu berperan sebagai probiotik yaitu Saccha-romyces cerevisiae (ragi tape). Saccharomyces cerevisiae yang dapat mengubah karbohidrat menjadi gula sederhana. Aktivitas mikroba ragi tape terjadi melalui beberapa mekanisme produksi enzim hidro-litik seperti amilase, proteinase, pektinase, lipase yang menyeder-hanakan polimer menjadi mono-mer yang lebih mudah diserap di dalam saluran pencernaan, selain itu fermentasi dengan ragi tape akan menghasilkan senyawa atau bahan organik terlarut yang mudah diserap seperti asam amino esensial dan disacharida serta sebagai sumber vitamin B. Saccharomyces cerevisiae dilaporkan dapat meningkatkan kecernaan pakan yang berserat tinggi. Proses fermentasi dengan ragi tape dapat menyebabkan perubahan terhadap komposisi kimia bahan seperti kandungan asam amino, lemak, karbohidrat, vitamin dan mineral akibat aktivitas dan perkembangbiakan mikroorganisme.

Saccaromyces

cerevisiae memiliki dua tipe sistem kerja enzim ekstraseluler: (1) Sistem hidrolitik, yaitu dengan cara menghasilkan enzim hidrolase 
yang bekerja merombak selulosa dan hemiselulosa, dan (2) Sistem oksidatif dan sekresi lignase ekstraseluler dengan cara depolimerisasi lignin (Perez et al., 2002). Keuntungan Saccaromyces cerevisiae adalah dapat meningkatkan kecernaan pakan (Ahmad, 2005). Penggunaan kultur Saccharomyces spp. sebagai suplemen probiotik maupun inokulan fermentasi ampas tahu akan dapat berfungsi ganda, yaitu dapat meningkatkan nilai nutrisi ampas tahu itu sendiri, dan bila produk fermentasi itu dikonsumsi oleh ayam, maka Saccharomyces spp. tersebut akan dapat berperan sebagai agensia probiotik dalam saluran pencernaan ayam (Mahfudz, 2006). Bidura et al. (2012) melaporkan bahwa suplementasi khamir Saccharomyces sp.dapat digunakan sebagai sumber probiotik dan dapat mendegradasi serat kasar ampas tahu. Menurut Saferi et al., (2005), Saccharomyces cerevisiae dapat menghasilkan enzim untuk menghidrolisa karbohidrat kompleks seperti selulosa, hemiselulose dan lignin. Ampas tahu fermentasi menghasilkan bahan pakan sumber protein kasar yang cukup tinggi, yaitu 28,36 \%, lemak 5,52\%, serat kasar $17,06 \%$ dan BETN 45,44\% (Nuraini et al., 2007). Hasil penelitian Sari et al. (2016), menunjukkan bahwa kandungan nutrisi ampas tahu yang difermentasi dengan Sacharomyces cerevisiae yaitu protein kasar $21,66 \%$, ME $2830 \mathrm{kkal} / \mathrm{kg}$, Ca $1,09 \%$, dan P $0,8 \%$.

Tujuan dari penelitian ini adalah untuk mengevaluasi pertambahan bobot badan dan efisiensi penggunaan protein pada broiler yang diberi ampas tahu hasil fermentasi dengan Saccharomyces cerevisiae.

\section{Metode Penelitian}

Penelitian ini dilakukan di Farm Fakultas Peternakan Universitas Jambi menggunakan 120 ekor ayam broiler umur 1 hari (DOC), Saccharomyces cerevisiae, pakan komersial dan ampas tahu.

\section{Fermentasi ampas tahu dengan} Khamir Saccharomyces cerevisiae.

Ampas tahu difermentasi menggunakan Saccharomyces cerevisiae sesuai petunjuk Suprapti et. al. (2008). Ampas tahu segar ditiriskan selama 1 malam untuk mengurangi kadar air, kemudian dikukus selama 45 menit dihitung sejak air kukusan mendidih. Kemudian didinginkan sampai suhu mencapai sekitra $30^{\circ} \mathrm{C}$. Setelah itu ditambahkan khamir Saccharomyces cerevisiae sebanyak $2 \%$ dan disemprotkan dengan larutan gula sebagai sumber energi bagi ragi sebanyak $2 \%$ sambil diaduk secara merata. Selanjutnya dimasukkan kedalam kantong 
polytilin yang telah dilobangi beberapa tempat untuk mendapatkan kondisi aerob dan diinkubasi pada suhu ruang selama 2 hari. Setelah itu dipanen, dikeringkan dan digiling sehingga menjadi tepung untuk dianalisa dan dicampurkan dengan pakan.

Hasil analisis Laboratorium Analisis Fakultas Peternakan Universitas Jambi (2018), diperoleh kandungan zat gizi ampas tahu tanpa fermentasi dan fermentasi yaitu bahan kering 94,83\% vs 93,75\%, Abu 2,57\% vs 3,04\%, Serat Kasar $17,35 \%$ vs 17,75\%, Lemak Kasar 6,99\% vs 2,45\% dan Protein Kasar 16,22\% vs 23,28\%. Sari et al., (2016), kandungan gizi ampas tahu yang difermentasi dengan Saccharomyces cerevisiae adalah energi metabolisme $2830 \mathrm{kkal} / \mathrm{kg}$, Ca 1,09\%, dan P 0,8\%. Untuk Kandungan gizi pakan percobaan fase starter dan finisher dapat dilihat pada Tabel 1.

\section{Rancangan Percobaan}

Penelitian didesain menggu-nakan Rancangan Acak Lengkap dengan 5 perlakuan dan 4 ulangan. Setiap ulangan terdiri dari 6 ekor. Perlakuan yang diberikan yaitu level pemberian tepung ampas tahu fermentasi yaitu :

P0 $=100 \%$ Pakan komersil (kontrol),

$\mathrm{P} 1=90 \% \quad$ Pakan komersil $+10 \%$ ampas tahu fermentasi,
P2 $=80 \%$ Pakan komersil $+20 \%$ ampas tahu fermentasi, P3 $=70 \%$ Pakan komersil $+30 \%$ ampas tahu fermentasi, $\mathrm{P} 4=60 \%$ Pakan komersil $+40 \%$ ampas tahu fermentasi.

Peubah yang diamati dalam penelitian ini adalah konsumsi ransum, konsumsi protein, dan rasio efisiensi penggunaan protein.

Data yang dihimpun dianalisis ragam sesuai rancangan yang digunakan. Pengaruh yang nyata antar perlakuan diuji lanjut menggunakan Uji Jarak Berganda Duncan (Steel and Torrie, 1999).

\section{Hasil Dan Pembahasan}

Pengaruh perlakuan terhadap parameter yang diamati dapat dilihat pada Tabel 2. Hasil analisis ragam menunjukkan bahwa penggunaan ampas tahu fermentasi nyata $(\mathrm{P}<0.05)$ menurunkan konsumsi ransum, terlihat bahwa penggunaan ampas tahu fermentasi sampai $20 \%$ belum menunjukkan pengaruhnya tetapi pada taraf penggunaan 30\% konsumsi ransum sudah menurun, hal ini diduga karena peningkatan penggunaan ampas tahu fermentasi dalam ransum berdampak pada peningkatan kandungan serat kasar ransum yang diakibatkan oleh tingginya kandungan serat kasar ampas tahu. Namun demikian, kandungan serat kasar ransum yang menggunakan 
Tabel 1. Komposisi Nutrisi Pada Pakan Percobaan Umur 0-4 minggu dan > 4 minggu

\begin{tabular}{lccccc}
\hline Kandungan Gizi & \multicolumn{5}{c}{ Perlakuan } \\
\cline { 2 - 6 } & P0 & P1 & P2 & P3 & P4 \\
\hline Pakan umur 0 - 4 minggu & & & & \\
\hline Protein kasar (\%) & 22,00 & 22,13 & 22,26 & 22,39 & 22,51 \\
Lemak kasar (\%) & 5,00 & 4,75 & 4,49 & 4,24 & 3,98 \\
Serat kasar (\%) & 5,00 & 6,28 & 7,55 & 8,83 & 10,10 \\
Ca (\%)* & 1,10 & 1,10 & 1,10 & 1,10 & 1,10 \\
P (\%)* & 0,80 & 0,80 & 0,80 & 0,80 & 0,80 \\
\hline Energi Metabolis (Kkal/Kg)* & 3100 & 3073 & 3046 & 3019 & 2992 \\
\hline Pakan umur > 4 minggu & & & & & \\
\hline Protein kasar (\%) & 20,00 & 20,33 & 20,66 & 20,99 & 21,32 \\
Lemak kasar (\%) & 5,00 & 4,75 & 4,49 & 4,24 & 3,98 \\
Serat kasar (\%) & 5,00 & 6,28 & 7,55 & 8,83 & 10,10 \\
Ca (\%)* & 1,10 & 1,10 & 1,10 & 1,10 & 1,10 \\
P (\%)* & 0,80 & 0,80 & 0,80 & 0,80 & 0,80 \\
\hline Energi Metabolis (Kkal/Kg)* & 3200 & 3113 & 3126 & 3089 & 3032 \\
\hline Ket: Sari eta. (2016). & & & & & \\
\hline
\end{tabular}

Ket: Sari et al., (2016).

ampas tahu sampai $20 \%$ masih dalam batas yang dapat ditolerir oleh ayam. Tingginya serat kasar akan menyebabkan semakin tinggi juga kandungan arabnoxylan, hal ini akan menyebabkan meningkatkan viscositas digesta usus yang mengakibatkan laju alir pakan dalam usus menjadi lebih lambat sehingga ayam merasa kenyang lebih lama. Sejalan dengan pendapat Jaroni, dkk (1999), yang melaporkan bahwa ransum yang mengandung serat kasar tinggi ( $\beta$-glucan dan arabinoxylan) dapat meningkatkan kekentalan digesta sehingga laju digesta dalam saluran pencernaan menurun dan berakibat turunnya konsumsi ransum. Selanjutnya
Amrullah (2004), juga menyatakan bahwa serat kasar yang tinggi menyebabkan unggas merasa kenyang, sehingga dapat menurunkan konsumsi karena serat kasar bersifat voluminous (amba). Hal ini menjelaskan bahwa ransum dengan tingkat keambaan yang tinggi dapat menimbulkan regangan lebih besar dan memberikan sensasi kenyang lebih cepat pada saat dikonsumsi ternak, sehingga sifat amba tersebut dapat membatasi konsumsi pada ternak dan Menurut Toharmat et al., (2006), keambaan bahan kaya serat dalam ransum akan membatasi konsumsi bahan kering ransum, Selanjutnya Wahyu (2004), juga menyatakan 
bahwa bahan pakan yang mengandung serat kasar yang tinggi mempunyai nilai energi yang rendah dan sebaliknya, apabila energi dalam ransum melebihi kebutuhan, maka konsumsi ransum akan sedikit (Wahju, 2004).

Penggunaan ampas tahu fermentasi tidak berpengaruh nyata $(\mathrm{P}>0.05)$ pada konsumsi protein, namun secara rataan terlihat adanya kecenderungan yang semakin menurun sejalan dengan penurunan konsumsi ransum, hal ini disebabkan karena konsumsi protein sangat ditentukan oleh konsumsi ransum. sejalan dengan pendapat Parakkasi (1990), bahwa konsumsi protein pada unggas sejalan dengan kuantitas ransum yang dikonsumsi. Namun demikian, walaupun konsumsi protein sama

Tabel 2. Rataan konsumsi ransum, konsumsi protein dan efisiensi penggunaan protein selama penelitian

\begin{tabular}{lcccl}
\hline Perlakuan & \multicolumn{4}{c}{ Peubah } \\
\cline { 2 - 5 } & $\begin{array}{c}\text { Konsumsi } \\
\text { ransum } \\
(\mathrm{gr} / \mathrm{ek} / \mathrm{mg})\end{array}$ & $\begin{array}{c}\text { Konsumsi } \\
\text { Protein } \\
(\mathrm{gr} / \mathrm{ek} / \mathrm{mg})\end{array}$ & $\begin{array}{c}\text { Efisiensi } \\
\text { Penggunaan } \\
\text { Protein }\end{array}$ & $\begin{array}{c}\text { Pertambahan } \\
\text { Bobot Badan } \\
(\mathrm{g} / \mathrm{ekor} / \mathrm{ming} \mathrm{gu})\end{array}$ \\
\hline P0 & $607.75 \pm 1.11 \mathrm{a}$ & $134.91 \pm 0.38 \mathrm{a}$ & $2.60 \pm 0.10 \mathrm{a}$ & $351.23 \pm 12.942 \mathrm{a}$ \\
P1 & $606.90 \pm 0.17 \mathrm{a}$ & $134.13 \pm 0.04 \mathrm{a}$ & $2.61 \pm 0.04 \mathrm{a}$ & $349.87 \pm 6.389 \mathrm{a}$ \\
P2 & $606.36 \pm 0.89 \mathrm{a}$ & $134.29 \pm 0.46 \mathrm{a}$ & $2.61 \pm 0.11 \mathrm{a}$ & $350.40 \pm 16.267 \mathrm{a}$ \\
P3 & $604.91 \pm 0.89 \mathrm{~b}$ & $133.27 \pm 0.83 \mathrm{a}$ & $2.29 \pm 0.08 \mathrm{~b}$ & $310.34 \pm 12.841 \mathrm{~b}$ \\
P4 & $602.86 \pm 0.74 \mathrm{~b}$ & $133.54 \pm 0.96 \mathrm{a}$ & $2.28 \pm 0.06 \mathrm{~b}$ & $305.47 \pm 8.17 \mathrm{~b}$ \\
\hline
\end{tabular}

Ket : Superskrip yang berbeda pada kolom yang sama menunjukkan berbeda nyata $(\mathrm{P}<0,05)$

Efisiesi penggunaan protein sampai taraf penggunaan ampas tahu fermentasi $20 \%$ masih sama dengan kontrol, tetapi semakin tinggi penggunaan ampas tahu fermentasi semakin rendah angka untuk semua perlakuan, terlihat bahwa semakin tinggi penggunaan ampas tahu fermentasi nyata $(\mathrm{P}<0.05) \quad$ menurunkan efisiensi penggunaan protein. Mahfudz et al. (2000) menyatakan bahwa kandungan serat kasar dalam ampas tahu yang tinggi menyebabkan proses penyerapan dalam pencernaan menjadi terhambat, karena unggas tidak mempunyai mikroorganisme yang mampu menghasilkan enzim selulose untuk memecah ikatan glikosidik $\beta-1-4$ pada selulosa (Mulyono, 2009). Hal ini dapat mempengaruhi viscositas digesta yang berakibat terhadap penurunan efisiensi penyerapan nutrien yang pada gilirannya berdampak langsung terhadap efiseiensi ransum dan performa ternak (Lesson dan Zubair, 2000). efisiensi penggunaan proteinnya. Keadaan ini masih sejalan dengan konsumsi protein, karena efisiensi penggunaan protein berhubungan erat dengan konsumsi protein, selain itu diduga bahwa $S$. 
cerevisiae dapat meningkatkan efisiensi penggunaan protein, karena $S$. cereviceae dapat meningkatkan aktifitas proteolitis dengan kemampuannya menghasilkan enzim protease sehingga meningkatkan kecernaan protein serta memperbaiki pertambahan bobot badan ayam broiler. Sesuai dengan pendapat Mulyono et al., (2009), yang menyatakan bahwa penggunaan probiotik $S$. cerevisiae dapat meningkatkan kecernaan protein dan rasio efisiensi penggunaan protein. Hal ini terkait dengan peran Saccharomyces cerevisiae sebagai probiotik dalam meningkatkan keseimbangan dan fungsi pencernaan serta dalam peningkatan penyerapan zat nutrien pakan. Nurhayati et al. (2019) melaporkan bahwa pakan yang mengandung bungkil inti sawit yang difermentasi dengan Aspergilus niger dapat diberikan pada puyuh sampai taraf $25 \%$ tanpa mempengaruhi efisiensi penggunaan protein dan terdapat kecenderungan peningkatan efisiensi penggunaan protein.

Hasil analisis ragam menunjukkan bahwa penggunaan ampas tahu fermentasi secara nyata $\quad(\mathrm{P}<0.05) \quad$ mempengaruhi pertambahan bobot badan. Uji Duncan menunjukkan bahwa sampai tahap $20 \%$ penggunaan ampas tahu fermentasi masih dapat ditolerir oleh broiler, namun pada tahap 30\% semua peubah sudah menunjukkan penurunan bobot badan. Hal ini diduga karena peningkatan penggunaan ampas tahu akan meningkatkan kekentalan cairan usus sehingga mengganggu proses penyerapan nutrisi, hal ini akan mengakibatkan penurunan kecepatan pertumbuhan. Sejalan dengan pendapat Varastegani dan Dahlan, (2014), yang menyatakan bahwa tingkat serat kasar dalam pakan sangat berpengaruh terhadap performa dan pertumbuhan ternak. Hasil penelitian Misnadi (2009), melaporkan bahwa pemberian pakan yang mengandung ampas tahu 30\% masih menghasilkan pertambahan bobot badan yang tidak berbeda dengan pakan kontrol, demikian juga dengan Hasil penelitian Trisnadewi et al., (2015), yang menyimpulkan bahwa penggunaan ampas tahu hasil fermentasi dengan kultur $S$. cerevisiae sampai level 30\% dalam pakan dapat meningkatkan penampilan itik Bali jantan. Hasil penelitian ini sejalan dengan hasil penelitian Sandi et al., (2012) yang menyatakan bahwa penambahan ampas tahu fermentasi sampai taraf $20 \%$ dalam pakan masih bisa ditolerir dibandingkan dengan pemberian $30 \%$ dan $40 \%$.

\section{Kesimpulan Dan Saran Kesimpulan}

Penggunaan ampas tahu fermentasi dengan Saccharomyces cerevisiae dalam ransum broiler dapat digunakan sampai taraf $20 \%$ untuk memperbaiki efisiensi penggunaan protein. 
Saran

Perlu pencampuran dedak ke dalam ampas tahu untuk mengurangi kadar air ampas tahu dan menambah waktu lama fermentasi untuk mengurangi kandungan serat kasar ampas tahu fermentasi.

\section{Daftar Pustaka}

Ahmad, R. Z. 2005. Pemanfaatan Khamir Saccharomyces cerevisiae untuk Ternak. Wartazoa 15 (1):49-55

Kementerian Pertanian Republik Indonesia. 2019. Luas Panen dan Produksi Kedelai Tahun 2014 - 2018.

http://www.pertanian.go.id $\angle$ home $/$ ?show $=$ page\&act $=$ vi ew\&id=61

Bidura, I.G. N. G., N. L. G. Sumardani, T. I. Putri, dan I. B. G. Partama. 2008. Pengaruh Pemberian Ransum Terfermentasi terhadap Pertambahan Berat Badan, Karkas, dan Jumlah Lemak Abdomenpada Itik Bali. Jurnal Pengembangan Peternakan Tropis 33 (4): 274-281.

Bidura, I.G.N.G., I.G. Mahardika, I. P. Suyadnya, I.B.G. Partama, I.G.L. Oka, D.P.M.A. Candrawati, and I.G.A.I. Aryani. 2012. The implementation of Saccharomyces spp.n-2 isolate culture
DOI: https://doi.org/10.22437/jiiip.v22i2.6725

(isolation from traditional yeast culture) for improving feed quality and performance of male Bali duckling. Agricultural Science Research Journal 2 (9): 486-492.

Huang, M.K., Y.J. Choi, R. Houde, J.W. Lee, B. Lee and X. Zhao. 2004. Effect of Lactobacilli and Acidophilic fungus on the production performance and immune responses in broiler chickens. Poult. Sci. 88 : 788795 .

Peraturan Menteri Pertanian Republik Indonesia Nomor 33/Permentan/OT.140/2/2014 Tanggal 24 Februari 2014. Pedoman Budi Daya Burung Puyuh yang Baik. Kementerian Pertanian Republik Indonesia. Jakarta.

Kaswinarni, F. 2007. Kajian Teknis Pengolahan Limbah Padat dan Cair Industri Tahu. Tesis. Program Pasca Sarjana Uuniversitas Diponegoro. Semarang.

Kompiang, L. P., T. Purwadaria, T. Haryati, and Suprijati. 1997. Bioconversion of Sago (Metroxylon sp) Waste Current Status of Agricultural Biotechnology in Indonesia. Darusman, A., L.P Kompiang and S. Moeljopawiro (Editors). AARD Indonesia. p. 523 - 526 
Kompiang, P. 2002. Pengaruh ragi: Saccharomyces cerevisiae dan ragi laut sebagai pakan imbuhan probiotik terhadap kinerja unggas. JITV. 7 (1) :18-21.

Lesson S. dan A.K. Zubair. 2000. Digestion in Poultry 11. Carbohydrates, Vitamin and Mineral. Departemen of animal and poultry science. University of Guelph Ontario. Canada.

Mahfudz 1.D., W. Sarengat dan B. Srigandono. 2000. Penggunaan ampas tahu sebagai bahan penyusun ransum ayam broiler. Prosiding Seminar Nasional Pengembangan Peternakan Lokal, Universitas Jendral Sudirman, Purwokerto.

Mahfudz, L. D. 2006. Ampas Tahu Fermentasi sebagai Bahan pakan Ayam Pedaging. Caraka Tani, Jurnal IlmuIlmu Pertanian 21 (1): 39 - 45.

Mathius, I. W. dan A.P. Sinurat. 2001. Pemanfaatan bahan pakan inkonvensional untuk ternak. Wartazoa, 11(2), 2031.

Nuraini, Sabrina and Suslina A. Latief. 2007. Improving the quality of tapioka by product through fermentation by Neurospora crasa to produce
DOI: https://doi.org/10.22437/jiiip.v22i2.6725

$\beta$ carotene rich feed. Pakistan Journal of Nutrition. 8(4) :487-490.

Nurhayati, Berliana and Nelwida. 2019. Protein Efficiency in Japanese Quail (Coturnixcoturnix Japonica) Fed Fermented Palm Kernel Cake by (Aspergillus niger). Iraqi Journal of Agricultural Sciences 50 (Special Issue): $128-133$.

Oboh, G. dan Elusiyan, C.A. (2007). Changes in the nutrient and antinutrient content of microfungi fermented cassava flour produced from low- and medium cyanide variety of cassava tuber. African Journal of Biotechnology 6(18): 2150-2157.

Parakkasi, A. 1990. Ilmu Gizi dan Makanan Ternak Monogastrik. Penerbit Angkasa, Bandung.

Perez J., J. Munoz-Dorado, T.de la Rubia, and J. Martinez. 2002. Biodegradation and Biological Treatments of Cellulose, Hemicellulose and Lignin: An Overview. Int. Microbiol. 5:53-63.

Sadzali, I. 2010. Potensi Limbah Tahu Sebagai Biogas. Jurnal UI Untuk Bangsa Seri 
DOI: https://doi.org/10.22437/jiiip.v22i2.6725

Kesehatan, Sains, dan Teknologi 1 (12) :62-69.

Saferi S., A.A.G. Emtiaz, S. Hajrasullha, and $\mathrm{H}$. Shariatmadari. 2005. Biodegradation of some agricultural Residues by Fungi in Agitated Submerged Cultures. Afr. J. Biotech. 4(10) $1058-1061$.

Sandi, S., R, Palupi dan Amyesti. 2012. Pengaruh Penambahan Ampas Tahu dan Dedak Fermentasi Terhadap Karkas, Usus dan Temak Abdomen Ayam Broiler. Agrinak. 02 (1);1-5.

Sari. N. M. L P., I.G.N.G Bidura., dan N.W Siti. 2016. Pengaruh Ransum yang Mengandung Ampas Tahu Difermentasi dengan Khamir Saccharomyces sp. Terhadap Komposisi Fisik Karkas Broiler Umur 6 Minggu. Peternakan Tropika. 4(1): 170 -183.

Steel, R. G. D dan J. H. Torrie, 1999. Prinsip dan Prosedur Statistik Suatu Pendekatan Biometrik. Alih Bahasa : B. Sumantri. PT. Gramedia, Jakarta.

Suprapti, S. W. H., J. Wahju, D. Sugandi, D. J. Samosir, N. R., A. Matjik and B.Tangenjaya. 2008. Implementasi dedak padi terfermentasi oleh
Asperrgilus ficum dan pengaruhnya terhadap ransum serta performens produksi ayam petelur. J. Indon. Trop. Anim. Agric. 33 (4) : 255-261.

Supriyati. 2003. Onggok terfermentasi dan pemanfaatannya dalam ransum ayam ras pedaging. JITV 8(3): $146-150$.

Suwarni, F.S. 2000. Pengaruh Penggunaan Dedak Fermentasi dalam Ransum Terhadap Bobot Badan Akhir, Bobot Karkas serta Perbandingan Daging dan Tulang Karkas Itik Tegal Jantan. Skripsi. Fakultas Peternakan Universitas Diponegoro. Semarang.

Toharmat, E. Nursasih, R. Nazilah, N. Hotimah, T. Q. Noerzihad, N.A. Sigit dan Y. Retnani 2006. Sifat Fisik Pakan Kaya Serat dan Pengaruhnya terhadap Konsumsi dan Kecernaan Nutrien Ransum pada Kambing. Media Peternakan, 29(3);146-154.

Trisnadewi, A. A. A. S., I. G. N. G. Bidura, A. T. Umiarti, Dan A. W. Puger. 2015. Pemanfaatan Ampas Tahu Terfermentasi dalam Ransum untuk Turunkan Akumulasi Lemak dan Kolesterol Tubuh Itik. 
Majalah Ilmiah Peternakan. 18 (2);55-60.

Varastegani A. and I. Dahlan. 2014. Influence of dietary fiber levels on feed utilization and growth performance in poultry.J Anim. Pro. Adv., 4(6): 422-429.

Wahju, J. 2004. Ilmu Nutrisi Unggas. Gadjah Mada University Press, Yogyakarta. 